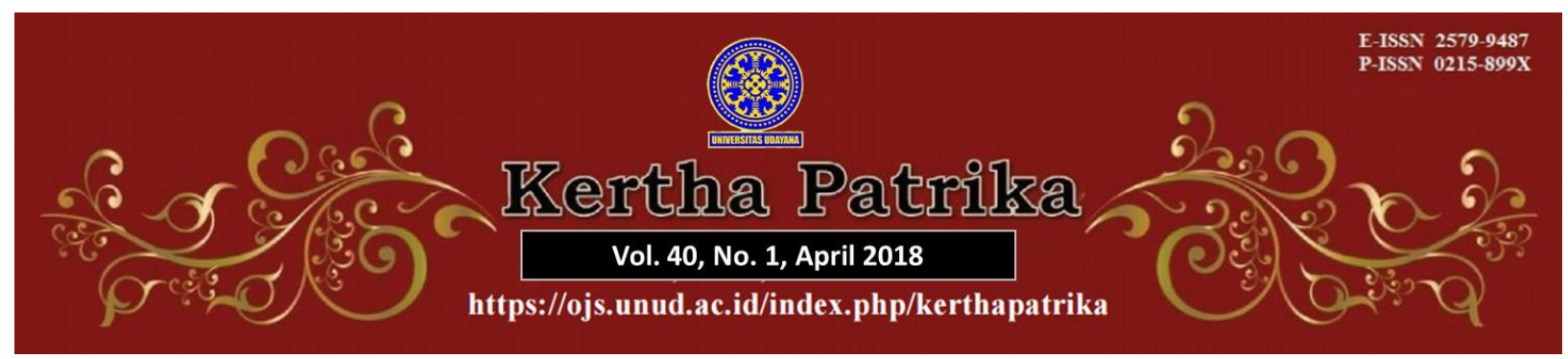

\title{
PENGATURAN HAK MILIK ATAS TANAH YANG DIALIHKAN UNTUK KEPENTINGAN UMUM PERSPEKTIF PERLINDUNGAN PEMILIK
}

\author{
Oleh: \\ Kadek Agus Bram Rendrajaya ${ }^{1}$ \\ Kantor Notaris dan PPAT I Gusti Ayu Sri Iryani, SH.,M.Kn
}

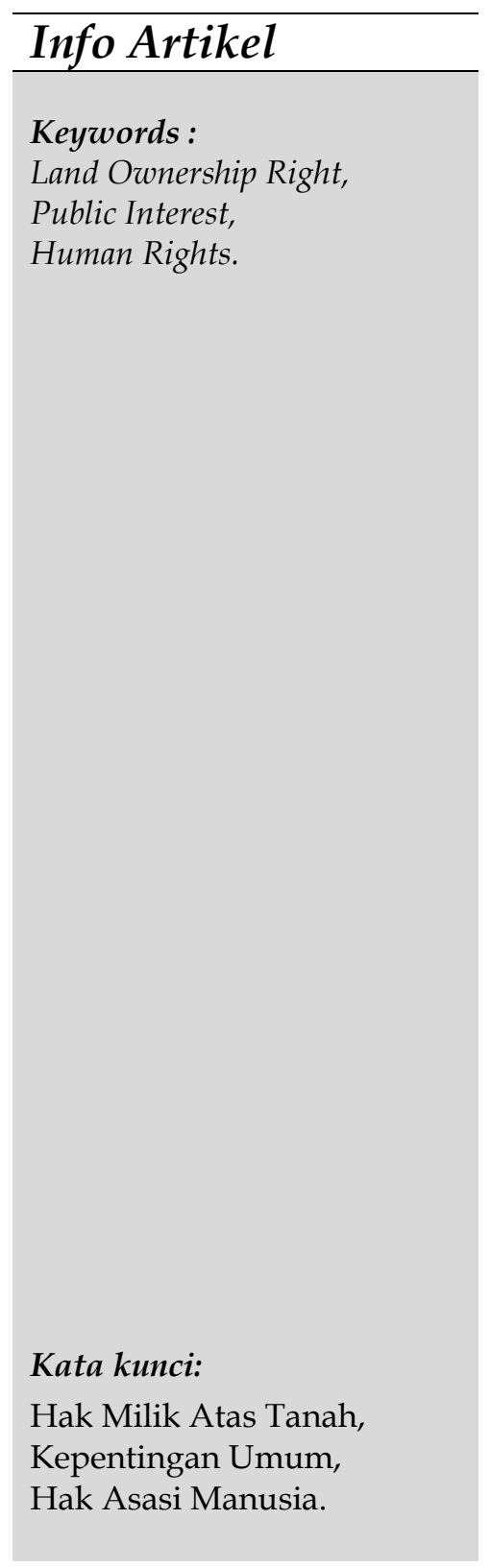

\begin{abstract}
Indonesia as a developing country is now intensively conducting development to provide public facilities and other needs to give prosperity to the people. One of the tools needed for the development is the land. The availability thereof is one of the inhibiting factors of the development process, moreover, half of the lands are owned by the society. Land ownership right is a part of the protection of human rights, which should get legal protection from the State. Problems arise when the land procurements that should ideally take concern on human rights were arbitrarily executed, including by the State. Therewithal, the purpose thereof should be intended for the public interest. Pursuant on that, this research aims to examine the problems: (1) How is the regulation on the legal protection for the ownership right holders of the land used for public interest in a manner consistent with human rights? And (2) What are the criteria of the public interest to determine a land procurement for development? This article is designed as a normative legal research with statute approach and conceptual approach that uses primary and secondary legal sources. Sources are collected by using the technique of document or literature study to be further analyzed descriptively, interpretatively, constructively, evaluatively, argumentatively, and systematically. The result of this research shows that (1) Land procurement for the public interest is administered by providing human rights protection of the ownership right holders, owing to the fact that the land procurement is executed by the State in accordance to the Law. (2) The use of society lands under the State's land procurement should be designated for the public interest. The public interest referred to in the Law is the interest of the Nations, State, and society that should be realized by the government and utilized for the great benefits of the society.
\end{abstract}

\begin{tabular}{l}
\hline Abstrak \\
\hline Indonesia sebagai Negara berkembang tengah gencar \\
dalam melakukan pembangunan guna memberikan \\
fasilitas publik maupun kebutuhan-kebutuhan lain untuk \\
memberikan kesejahteraan bagi masyarakat. Salah satu
\end{tabular}

1 Kadek Agus Bram Rendraya adalah staff pada Kantor Notaris dan PPAT I Gusti Ayu SriIryani, SH., M.Kn. Korespondensi dengan penulis melalui email: bram.ability@yahoo.com. 


Corresponding Author:
Kadek Agus Bram
Rendrajaya
E-mail:
bram.ability@yahoo.com
DOI:
10.24843/KP.2018.v40.i01.p04

\section{Pendahuluan}

Indonesia sebagai negara berkembang tengah gencar dalam melakukan pembangunan guna memberikan fasilitas publik maupun kebutuhan-kebutuhan lain untuk memberikan kesejahteraan bagi masyarakat. Salah satu sarana yang dibutuhkan dalam pembangunan adalah tanah yang merupakan bentuk karunia yang diberikan Tuhan pada negara. Untuk itulah supaya tidak timbul masalah, pemerintah berusaha mengaturnya dengan baik. Keadaan Indonesia sebagai Negara berkembang menuntut pemerintah melakukan banyak perbaikan dan pembangunan. Terkait dengan pembangunan di atas tanah hak milik yang dimiliki oleh masyarakat tentunya harus mendapatkan persetujuan dari pemegang haknya agar tidak terjadi kesewenangwenangan oleh pemerintah yang dapat melanggar hak asasi manusia terhadap hak milik atas tanah. Dalam rangka untuk melindungi Hak Asasi Manusia dari kebijakan atau tindakan sewenang-wenang penguasa, dalam konsep rechtstaat yang menonjolkan 
asas legalitas yang mengharuskan tindak pemerintah harus sesuai dengan hukum. ${ }^{2}$ Sesuai asas legalitas dapat dipahami bahwa peraturan perundang-undangan dan yang tertulis harus melandasi tindakan pemerintah. ${ }^{3}$

Perlindungan terhadap Hak Asasi Manusia di Indonesia diatur dalam konstitusi Indonesia khususnya dalam Pasal 28A sampai Pasal 28J. Lebih lanjut diatur dalam Undang-Undang Hak Asasi Manusia. Terkait dalam perlindungan hak asasi manusia, hak milik atas tanah merupakan hak asasi yang dilindungi Negara. Seperti yang tertuang dalam Pasal 28H ayat (4) UUD-NRI 1945 yang menentukan "Negara melindungi hak milik masyarakat dan tidak dapat diambil secara sewenang-wenang oleh siapapun". Sehingga dalam kondisi ini negara membentuk peraturan untuk memberikan mekanisme bagi Pengadaan tanah yang akan digunakan untuk pembangunan. Sehingga atas alasan-alasan tersebut Undang-Undang Nomor 2 Tahun 2012 tentang Pengadaan Tanah Bagi Pembangunan Untuk Kepentingan Umum (Selanjutnya ditulis Undang-Undang Pengadaan Tanah Untuk Kepentingan Umum) hadir diharapkan memberikan kepastian, keadilan dan kemanfaatan bagi semua pihak sesuai dengan tujuan hukum. Namun permasalahan tidak berhenti sampai disini, setelah melalui proses inventarisasi tanah yang akan digunakan untuk kepentingan umum, Gubernur dapat menetapkan tanah bilamana keberatan yang diajukan pihak yang berhak atas tanah telah ditolak. Berdasarkan Pasal 22 Undang-Undang Pengadaan Tanah Bagi Pembangunan Untuk Kepentingan Umum dapat dicermati sesungguhnya memberi peluang bilamana tidak terjadi kesepakatan maka berdasarkan keputusan Gubernur setempat, negara dapat mengambil paksa Tanah yang akan digunakan untuk Pembangunan. Permasalahannya adalah ketika masyarakat tidak sepakat untuk melepas tanahnya kepada pemerintah, baik alasan historis maupun ganti rugi yang tidak sesuai maka Negara dapat mengambil tanah secara paksa. Sedangkan Undang-Undang HAM melindungi hak milik yang tidak membolehkan mengambil paksa secara sewenang-wenang. Maka dari itu dapatlah dikatakan bahwa Undang-Undang tersebut sudah memenuhi unsur tidak mengambil tanah hak milik masyarakat secara sewenang-wenang sehingga tidak melanggar Hak Asasi Manusia dan hak masyarakat tersebut dilindungi oleh Konstitusi maupun Undang-Undang HAM.

Penelitian tentang pengaturan perlindungan hukum terhadap pemegang hak milik atas tanah yang berlandaskan hak asasi manusia merupakan penelitian dengan isu hukum yang menarik, serta sangat urgen untuk dilakukan. Permasalahan yang dikaji meliputi: Bagaimanakah pengaturan perlindungan hukum terhadap pemegang hak milik atas tanah yang digunakan untuk kepentingan umum ditinjau dari hak asasi manusia? serta Apakah kriteria kepentingan umum dalam penetapan pengadaan tanah bagi pembangunan?

\section{Metode Penelitian}

\footnotetext{
2 Bahder Johan Nasution. (2014). Negara Hukum dan Hak Asasi Manusia. Mandar Maju. Bandung, h. 10.

${ }^{3}$ Ibid., h. 21
} 
Metode hukum normative digunakan dalam kajian ini, yaitu suatu jenis penelitian yang mengkaji norma hukum yang dijadikan pedoman dalam berperilaku oleh masyarakat dan setiap orang. ${ }^{4}$ Pendekatan petundang-undangan dan pendekatan konsep digunakan dalam kajian ini.Bahan hukum yang dikaji adalah bahan hukum primer dan sekunder, yang dikumpulkan dengan tehnik dokumentasi serta dianalisis dengan langkah-langkah deskriptif, sistematisasi, interprestasi, eksplanasi dan argumentasi.

\section{Hasil dan Pembahasan}

\subsection{Pengadaan Tanah bagi Pembangunan untuk Kepentingan Umum yang Menggunakan Tanah Hak Milik Masyarakat.}

Pemerintah dalam mewujudkan pengadaan tanah haruslah memperhatikan kemanfaatan bagi kemakmuran sebesar-besarnya bagi masyarakat. Demikian juga penyelenggaraan pembangunan yang diwujudkan pemerintah diatur dalam Pasal 10 Undang-Undang Nomor 2 Tahun 2012 tentang Pengadaan Tanah Bagi Pembangunan Untuk Kepentingan Umum. Jika dicermati ada berbagai model berkaitan dengan pengalihan ha katas tanah yaitu: melalui jual beli, penyerahan ha katas tanah maupun pencabutan ha katas tanah. Proses pengadaan tanah melalui peristiwa jual beli maupun tukar menukar didasarkan pada kesepakatan para pihak secara sukarela. yakni pemegang hak atas tanah dan pihak yang membutuhkan tanpa paksaan dan/atau campur tangan dari pihak lain (pemerintah). Proses pengadaan tanah seperti itu yang paling ideal karena didasarkan pada kebebasan dan kesepakatan para pihak tanpa adanya unsur paksaan/campur tangan dari pihak manapun, melainkan didasarkan pada kesepakatan para pihak secara sukarela mengenai tanah dan harganya. Sebagaimana dikemukakan sebelumnya model pelepasan juga digunakan untuk pengadaan tanah.

Bilamana model jual beli tidak berhasil dalam pengadaan tanah bagi pembangunan untuk kepentingan umum, tampaknya sebagai jalan terakhir dapat menggunakan model pencabutan hak atas tanah., model ini menjadi relevan dilakukan karena untuk kepentingan umum. Lebih lanjut dengan mencermati Pasal 38 Undang-Undang Nomor 2 Tahun 2012 tentang Pengadaan Tanah Bagi Pembangunan Untuk Kepentingan Umum, dapat diketahui bahwa berkaitan dengan tidak terjadinya kesepakatan atas ganti rugi, pihak yang berhak dapat mengajukan keberatan kepada pengadilan negeri, kemudian hingga ke tahap kasasi. Terhadap ketentuan diatas, terlihat bahwa mengenai besarnya nilai ganti rugi dalam pengadaan tanah oleh Pemerintah yang menggunakan tanah hak milik masyarakat, maka Pengadilan atau Mahkamah Agung sebagai penegak hukum dan keadilan tertinggi yang akan memutuskan. Pemerintah tidak bisa sewenang-wenang melakukan pembayaran ganti rugi tersebut.

Berdasarkan ketentuan-ketentuan diatas bila dicermati lebih dalam berdasarkan teori Negara Hukum bahwa Negara Indonesia sebagai Negara hukum, telah menggunakan landasan undang-undang berkaitan dengan pembebasan ha katas tanah, khususnya melalui Undang-Undang Nomor 2 Tahun 2012. Undang-Undang merupakan produk

\footnotetext{
${ }^{4}$ Abdulkadir Muhammad. (2004). Hukum dan Penelitian Hukum. Citra Aditya Bakti. Bandung, h. 52. (selanjutnya disebut Abdulkadir Muhammad I).
} 
sah yaitu salah satu bagian dari struktur tata hukum di Indonesia. Jadi kegiatan pengadaan tanah, khususnya untuk kepentingan umum, sesungguhnya merupakan tindakan legal berdasarkan Teori Negara Hukum dan Teori Peraturan Perundangundangan karena kegiatan tersebut telah didasari oleh peraturan hukum dalam bentuk Undang-Undang.

\subsection{Hak Milik Atas Tanah Perspektif Perlindungan Hak Asasi Manusia.}

Berdasarkan Pasal 36 Undang-Undang tentang Hak Asasi Manusia dapat dicermati bahwa pada intinya ha katas tanah dapat dimiliki oleh setiap orang baik secara sendiri maupun bersama dengan orang lain. Konteks perlindungan HAM juga terlihat jelas melalui ketentuan yang tidak membolehkan siapapun merampas hak milik secara sewenang-wenang, serta Hak milik mempunyai fungsi sosial. Mariam Darus Badrulzaman mengemukakan berkaitan dengan hak milik berfungsi sosial bahwa kemutlakan hak milik atas tanah dalam hukum perdata, dapat dilihat dari 5 (lima) ciri yaitu adanya Hak menikmati secara leluasa , hak terkuat, sesuai perundang-undangan , tidak mengganggu hak orang lain, serta pencabutan hak untuk kepentingan umum dibarengi dengan ganti rugi. ${ }^{5}$ Dengan demikian itu berarti terkait prinsip dalam fungsi sosial dapat dipahami kepentingan umum tidak mendesak kepentingan perorangan. Sebagaimana diamanahkan Pasal 2 Ayat (3) UUPT, maka tujuan UUPA akan tercapai manakala antara kepentingan masyarakat dan perorangan saling berimbang, dan pada akhirnya masyarakat diharapkan menikmati kemakmuran, keadilan, dan kebahagiaan.

Berkaitan dengan Teori Hak Asasi Manusia, pelaksanaan pengadaan tanah untuk kepentingan umum wajib memperhatikan hak-hak yang dimiliki masyarakat terutama hak milik atas tanah. Namun menurut cara pandang HAM di Indonesia yakni paham monodualis yang memandang HAM tidak hanya sebagai individu melainkan juga sebagai mahkluk sosial. ${ }^{6}$ Selain itu hak asasi manusia tidak pernah dimaksudkan untuk memberikan kebebasan atau hak otonomi individual tanpa batas di luar sistem kehidupan sosial politik, melainkan memperjuangkan bagaimana individu-individu dapat berintegrasi membentuk suatu sistem kehidupan yang menjamin hak-hak tersebut. Terjaminnya hak-hak milik tersebut dalam pelaksanaan pengadaan tanah harus didasari dengan Undang-Undang dan Undang-Undang dibuat oleh rakyat yang diwakili oleh Dewan Perwakilan Rakyat sebagai representasi dari rakyat dalam membuat peraturan hukum yang mengikat bagi rakyat itu sendiri. Pengaturan demikian dimaksudkan agar kesewenang-wenangan tidak terjadi. Pencegahan kesewenang-wenangan tersebut melalui adanya dasar hukum dan mekanisme yang harus dilalui dalam pelaksanaan pengadaan tanah, tujuannya harus untuk kepentingan umum dan juga ganti rugi yang sesuai dan/atau disepakati oleh pemilik hak tersebut.

\subsection{Kedudukan Hak Milik dan Hak Menguasai Atas Tanah dalam Hukum Agraria}

\footnotetext{
${ }^{5}$ Mariam Darus Badrulzaman. (1997). Mencari Sistem Hukum Banda Nasional. Alumni. Bandung, h. 128

6 Suko Wiyono. (2011). Hak Asasi Manusia (HAM) dalam Kerangka Negara Hukum yang Demokratis Berdasarkan Pancasila, dalam buku Demokrasi, HAM, \& Konstitusi Persepektif Negara Bangsa untuk Menghadirkan Keadilan (Kado untuk Sang Guru Prof. Dr. I Dewa Gede Atmadja, SH,. MS.). Setara Press (Kelompok Penerbit Intrans). Malang, h. 186.
} 
Adapun hak-hak penguasaan tanah itu tersusun dalam tata urutan (hierarki) yang menurut Boedi Harsono adalah sebagai berikut:

1.Hak Bangsa Indonesia

2.Hak Menguasai oleh negara atas tanah

3. Hak ulayat masyarakat hukum adat

4.Hak-hak perseorangan ${ }^{7}$

Menurut Boedi Harsono bahwa hak bangsa seperti yang dijelaskan pada Pasal 1 UUPA, merupakan hak penguasaan atas tanah yang tertinggi dalam hukum tanah nasional. Hak-hak penguasaan tanah yang lain, secara langsung maupun tidak langsung bersumber padanya. ${ }^{8}$ Dengan kata lain bahwa Hak Milik Bangsa terdiri dari Hak Milik Pribadi dan Hak Milik Publik. Maka hak penguasaan negara harus dimaknai sebagai kewenangan yang bersumber dari pendelegasian hak bangsa Indonesia yang dalam penerapannya dibatasi oleh hak privat dan hak publik.

Berdasarkan Konsep Perlindungan Hukum maka tanah hak milik masyarakat merupakan salah satu bagian dari pada hak yang dilindungi oleh hukum di Indonesia. Hal tersebut dapat disebutkan negara karena mengakui hak-hak yang diberikan kepada pemilik hak, hanya saja Negara memiliki kekuasaan lebih tinggi dibandingkan hak milik masyarakat. Kekuasaan Negara atas tanah juga tidak boleh sewenangwenang dan mengabaikan hak milik masyarakat, maka dari itu setiap tindakan pendayaan tanah hak milik masyarakat oleh Negara harus didasari dengan UndangUndang yang menjamin perlindungan hukum hak milik masyarakat baik secara preventif maupun represif.

\subsection{Tolok Ukur Kepentingan Umum Dalam Pengadaan Tanah Bagi Pembangunan.}

Pemerintah memang sudah seharusnya mewujudkan kepentingan umum, termasuk berkaitan dengan pengadaan tanah. Sebagaimana diatur dalam Pasal 10 UndangUndang pengadaan Tanah, diklasifikasikan jenis pembangunan yang dimaksud untuk kepentingan umum diantaranya tanah tersebut ditujukan untuk keamanan nasional, rumah sakit pemerintah cagar alam dan sebagainya.

Berdasarkan Konsep Kepentingan Umum, bahwa kepentingan umum adalah kepentingan pemerintah, kepentingan masyarakat dan kepentingan antar bangsa. ${ }^{9}$ Pembangunan untuk kepentingan umum harus memenuhi kebutuhan hidup masyarakat atau dengan kata lain pembangunan tersebut harus dirasakan manfaatnya oleh sebagian besar masyarakat baik secara langsung maupun tidak langsung. Kepentingan umum merupakan tujuan utama pengadaan tanah oleh pemerintah sehingga pembangunan tersebut harus dapat dimanfaatkan oleh setiap lapisan masyarakat.

\subsection{Mekanisme Pengadaan Tanah Yang Digunakan Untuk Kepentingan Umum.}

\footnotetext{
7 Ibid., h.267

8 Boedi Harsono. (1999). Hukum Agraria Indonesia: Sejarah Pembentukan Undang-Undang Pokok Agraria, Isi dan Pelaksanaannya. Djambatan. Jakarta, h. 266.

9 Ibrahim R. (1997). Prospek BUMN dan Kepentingan Umum. PT. Citra Aditya Bakti. Bandung, h. 187.
} 
Mekanisme pengadaan tanah yang digunakan di Indonesia sebagaimana telah dikemukakan sebelumnya berlandaskan pada Undang-Undang yang mekanismenya melalui beberapa tahapan yaitu: perencanaan, persiapan, pelaksanaan dan penyerahan hasil. Dengan mencermati Teori Negara Hukum sebagaimana dikemukakan oleh Friedrich Julius Stahl bahwa unsur-unsur Negara hukum harus adanya jaminan perlindungan HAM, adanya pembagian kekuasaan berdasarkan trias politica, tindakan pemerintah berdasarkan undang-undang, dan adanya pengadilan administrasi Negara. Bila dikaitkan dengan mekanisme dalam Pengadaan tanah sebagaimana telah dikemukakan sebelumnya yang berfokus untuk pembangunan juga memperhatikan kepentingan umum, maka jaminan perlindungan HAM harus dikedepankan. Jaminan perlindungan HAM dalam suatu peraturan perundang-undangan adalah melindungi dan mengakui hak milik tanah masyarakat. Melalui mekanisme pendataan pemilikan tanah, kemudian proses musyawarah oleh pemilik tanah dan instansi pemerintah yang membutuhkan tanah dan kemudian adanya kesepakatan untuk penetapan nilai ganti rugi terhadap pengadaan tanah yang menggunakan tanah hak milik masyarakat. Pembagian kekuasaan berdasarkan trias politica yakni Lembaga Yudikatif, Legislatif dan Eksekutif memiliki peran sinergis dalam persoalan tanah, khususnya untuk kepentingan umum. Keberadaan lembaga legislatif berperan untuk membuat peraturan perundang-undangan, termasuk dalam pengadaan tanah. Lebih lanjut, lembaga yudikatif berperan memutuskan manakala tidak tercapai musyawarah, melalui putusan pengadilan diharapkan tercapai putusan yang seadil-adilnya terhadap kelanjutan pelaksanaan pengadaan tanah maupun d menetapkan ganti kerugian atas pengadaan tanah. Pada akhirnya, lembaga Eksekutif menjalankan perintah undang-undang dalam melaksanakan pengadaan tanah untuk kepentingan umum, misalnya melalui Gubernur setempat melakukan pendataan dan sosialisasi terhadap pengadaan tanah kepada masyarakat pemilik tanah maupun masyarakat sekitar yang terimbas dapat akibat rencana pembangunan.

Dalam negara hukum, tindakan pemerintah yang berlandaskan undang-undang merupakan salah satu unsur yang penting, Undang-undang merupakan produk hukum yang dibuat oleh Dewan Perwakilan Rakyat, yaitu wakil rakyat yang dipilih langsung oleh rakyat. Sehingga tindakan pemerintah yang didasarkan oleh undangundang merupakan tindakan yang telah mendapat persetujuan dari masyarakat itu sendiri.

Pengadilan administrasi negara memiliki peran serta dalam pelaksanaan pengadaan tanah bilamana dalam musyawarah tidak ditemui kesepakatan antara pemerintah atau instansi yang memerlukan tanah dan masyarakat yang tanahnya akan digunakan untuk pembangunan. Pengadilan administrasi negara memutuskan lanjut atau tidaknya proses pembangunan dan juga memutuskan jumlah besaran ganti rugi yang diterima oleh masyarakat pemilik tanah yang digunakan bagi pembangunan untuk kepentingan umum.

\section{Kesimpulan}


Penggunaan tanah masyarakat untuk kepentingan umum dan pembangunan sudah sesuai dengan ketentuan undang-undang sebagaimana diatur dalam Konstitusi Indonesia maupun Undang-Undang Nomor 2 tahun 2014 serta tidak merupakan tindakan sewenang-wenang negara. Penggunaan tanah melalui pengadaan tanah oleh Negara yang menggunakan tanah hak milik masyarakat harus ditujukan untuk kepentingan umum, serta sebesar-besarnya untuk untuk kemakmuran masyarakat. Penyelenggaraan pengadaan tanah wajib dilakukan melalui mekanisme yang memenuhi tahapan: perencanaan, persiapan, pelaksanaan dan penyerahan hasil. Sehingga melalui mekanisme yang sesuai dengan perintah undang-undang, keseimbangan antara kepentingan pembangunan dan kepentingan masyarakat dapat tercapai.

\section{Daftar Pustaka}

\section{Buku}

Abdulkadir Muhammad. (2004). Hukum dan Penelitian Hukum. Citra Aditya Bakti. Bandung.

Badrulzaman, Mariam Darus. (1997). Mencari Sistem Hukum Banda Nasional. Alumni. Bandung.

Harsono, Boedi. (1999). Hukum Agraria Indonesia: Sejarah Pembentukan Undang-Undang Pokok Agraria, Isi dan Pelaksanaannya. Djambatan. Jakarta.

Ibrahim R. (1997). Prospek BUMN dan Kepentingan Umum. PT. Citra Aditya Bakti. Bandung.

Nasution, Bahder Johan. (2014). Negara Hukum dan Hak Asasi Manusia. Mandar Maju.

Wiyono, Suko. (2011). Hak Asasi Manusia (HAM) dalam Kerangka Negara Hukum yang Demokratis Berdasarkan Pancasila, dalam buku Demokrasi, HAM, \& Konstitusi Persepektif Negara Bangsa untuk Menghadirkan Keadilan (Kado untuk Sang Guru Prof. Dr. I Dewa Gede Atmadja, SH,. MS.). Setara Press (Kelompok Penerbit Intrans). Malang.

\section{Peraturan Perundang-Undangan}

Undang-Undang Dasar Negara Republik Indonesia Tahun 1945

Undang-Undang Nomor 5 Tahun 1960 tentang Peraturan Dasar Pokok-Pokok Agraria, Lembaran Negara 1960-104, Tambahan Lembaran Negara Republik Indonesia Tahun 1960 Nomor 104.

Undang-Undang Nomor 39 Tahun 1999 tentang Hak Asasi Manusia,Lembaran Negara Republik Indonesia Tahun 1999 Nomor 165, Tambahan Lembaran Negara Republik Indonesia Tahun 1999 Nomor 165.

Undang-Undang Nomor 2 Tahun 2012 tentang Pengadaan Tanah Bagi Pembangunan Untuk Kepentingan Umum, Lembaran Negara Republik Indonesia Tahun 2012 Nomor 22, Tambahan Lembaran Negara Republik Indonesia Tahun 2012 Nomor 22 